Article

\title{
Effect of Natural Organic Matter on the Ozonation Mechanism of Trimethoprim in Water
}

\author{
Ning Zhang, Beihai Zhou, Rongfang Yuan *, Fei Wang and Huilun Chen * \\ Beijing Key Laboratory of Resource-Oriented Treatment of Industrial Pollutants, Department of Environmental \\ Science and Engineering, University of Science and Technology Beijing, Beijing 100083, China; \\ g20188215@xs.ustb.edu.cn (N.Z.); zhou_beihai@126.com (B.Z.); wangfei@ustb.edu.cn (F.W.) \\ * Correspondence: yuanrongfang@ustb.edu.cn (R.Y.); chenhuilun@ustb.edu.cn (H.C.); \\ Tel.: +86-10-62332465 (R.Y.)
}

Received: 16 September 2020; Accepted: 16 October 2020; Published: 21 October 2020

check for updates

\begin{abstract}
Trimethoprim (TMP) is often used for the treatment of various bacterial infections. It can be detected in water, and it is difficult to be biodegraded. In this study, the degradation mechanism of TMP through ozonation and the effect of humic acids (HA) were investigated. Excessive ozone $\left(\mathrm{pH} 6,0{ }^{\circ} \mathrm{C}\right.$ ) could reduce the content of TMP to less than $1 \%$ in $30 \mathrm{~s}$. However, when ozone $\left(\mathrm{O}_{3}\right)$ was not excessive $\left(\mathrm{pH} 6,20^{\circ} \mathrm{C}\right)$, the removal efficiency of TMP increased with the increase of $\mathrm{O}_{3}$ concentration. Four possible degradation pathways of TMP in the process of ozonation were speculated: hydroxylation, demethylation, carbonylation, and cleavage. The presence of HA in water inhibit the generation of ozonation products of TMP. The excitation-emission matrices (EEM) analysis showed that with the extension of ozonation time, the fluorescence value in the solution decreased and the fluorescence peak blue shifted. These results indicated that the structure of HA changed in the reaction and was competitively degraded with TMP. According to the free radical quenching test, the products of pyrolysis, direct hydroxylation and demethylation were mainly produced by indirect oxidation.
\end{abstract}

Keywords: trimethoprim; ozonation; humic acids; direct oxidation; degradation pathways

\section{Introduction}

In recent years, the emerging persistent organic matter attracted great attention in the environmental protection industry [1-3]. Owing to their high consumption and refractory chemical properties [4], antibiotics are considered as a new persistent organic substances [5-7]. Antibiotics enter the aquatic environment through industrial and medical wastewater from the pharmaceutical industry [8,9], as well as human and animal feces [10]. Trimethoprim (TMP) is a commonly used antibacterial synergetic agent which can be combined with sulfonamides to greatly enhance their antibacterial activity [11,12]. It is widely used in the treatment of human diseases and animal bacterial infections [13,14]. Only $25 \%$ of TMP can be metabolized by human body after ingestion [15], and the remaining TMP and its metabolites are discharged out of the body through the digestive system and subsequently enter domestic wastewater [16-18]. TMP has been detected in wastewater from sewage treatment plants, surface water environment, drinking water, and other water bodies [19-23]. Even in large-scale wastewater treatment plants with advanced technologies such as chlorination and ultraviolet disinfection radiation, the concentration of TMP in the effluent ranges from the ng/L to the $\mu \mathrm{g} / \mathrm{L}$ level $[24,25]$. TMP in water cannot be effectively removed through the existing traditional wastewater treatment processes [26-28]. Therefore, exploring an efficient and environmentally friendly technology to degrade TMP in water is of great significance. At present, some advanced technologies and materials have been studied to treat refractory wastewater. For instance, it was reported that 
MBR technology can effectively degraded TMP from hospital wastewater [29]. Sharma et al. [30-32] discovered nanofiber membrane for wastewater treatment, which greatly reduced the cost of membrane technology. In addition, advanced oxidation processes (AOPs) have been studied to eliminate TMP, including photolysis [33], photo-Fenton [34], photocatalysis [35], ozonation, and so on.

$\mathrm{O}_{3}$ was often used in water treatment [36,37], and was demonstrated to oxidize antibiotics [38]. $\mathrm{O}_{3}$ is one of the strongest oxidizing substances in nature, and its oxidation potential can reach $2.07 \mathrm{~V}[39,40]$. There are two modes of reaction between $\mathrm{O}_{3}$ and organic pollutants in aqueous solution. The first mode is the direct reaction of $\mathrm{O}_{3}$ molecules with organic pollutants. The second mode is the decomposition of $\mathrm{O}_{3}$ to produce hydroxyl radicals $(\cdot \mathrm{OH})$, which then reacts with organic pollutants [41]. The reduction product of $\mathrm{O}_{3}$ is oxygen, which will not bring secondary pollution. Most antibiotics (e.g., amoxicillin, doxycycline, ciprofloxacin, and sulphadiazine) can readily react with $\mathrm{O}_{3}$ [42]. TMP is an organic compound with a high $\mathrm{O}_{3}$ reaction rate constant $\left(k=2.7 \times 10^{5} \mathrm{M}^{-1} \mathrm{~s}^{-1}\right.$ at $\mathrm{pH}$ 7) [43-45]. Therefore, TMP can be directly removed by $\mathrm{O}_{3}$ oxidation. Moreover, TMP can be removed by $\mathrm{OH}$ produced by $\mathrm{O}_{3}$ decomposition $\left(k=6.9 \times 10^{9} \mathrm{M}^{-1} \mathrm{~s}^{-1}\right.$ at $\mathrm{pH}$ 7) [46]. Ling et al. [47] found that norfloxacin and levofloxacin had high reactivity to $\mathrm{O}_{3}$. Kuang et al. discovered that TMP can be effectively removed when the molar ratio of $\mathrm{O}_{3}$ dose to TMP reached 3 [48]. In addition, four degradation pathways of TMP were proposed in this reference: hydroxylation, carbonylation, deamination, and demethylation. As a common free radical quencher, methanol was used to distinguish between direct and indirect oxidation [49]. Ozonation has been shown to have a high potential for the oxidation of pharmaceuticals in drinking water [37] and wastewater [50]. Although in practice, the amount of ozone used in water treatment can only lead to partial oxidation; however, partial oxidation was sufficient to significantly reduce pharmacological activity and toxicity. The ozone-derived oxidation products formed from parent pharmaceutical compounds may be more susceptible to biological degradation [37].

Natural organic matters (NOM), such as humic acids (HA), are present in water [51,52]. The presence of these NOM which may react directly with $\mathrm{O}_{3}$ or indirectly with free radicals will affect the ozonation of TMP. Therefore, the presence of $\mathrm{HA}$ will reduce the amount of $\mathrm{O}_{3}$ and $\cdot \mathrm{OH}$, and lead to the decrease of the oxidation rate of micro pollutants [53]. At present, many researches focus on the effect of NOM on the photocatalytic degradation of antibiotics as a photosensitizer [54]. However, study on the effect of HA on the ozonation of TMP and its pathway is limited.

To summarize, most of the studies only focused on the effect of HA on the degradation rate of TMP by ozonation, as for the degradation pathway, most of the studies just stayed in pure solution. This study not only discusses the effect of HA on the degradation effect, but also compares the change of intermediate products in the degradation process. In addition, the effect of methanol on the experiment was also studied. The normalized abundances of the intermediate products of TMP in water in the presence and absence of HA during ozonation process were detected by using HPLC-MS/MS to explore the degradation mechanisms of TMP. Methanol, which can inhibit the oxidation of TMP by $\cdot \mathrm{OH}$, was added to the solution to judge the main method of reaction. The results reflect that $\cdot \mathrm{OH}$ played an important role in the reaction. In addition, the 3D-EEM analysis of the solution with HA addition was carried out to discuss the change of the fluorescent substance during the experiment. This study could provide theoretical basis for the control of TMP and its ozonation products during water treatment.

\section{Materials and Methods}

\subsection{Reagents}

The solutions were prepared using corresponding chemical reagents with high purity. TMP (>99\%) was purchased from Sigma-Aldrich (St. Louis, MO, USA). Methanol (HPLC-grade, $\mathrm{CH}_{3} \mathrm{OH}$ ), acetonitrile (HPLC-grade, $\mathrm{CH}_{3} \mathrm{CN}$ ), and formic acid $(\mathrm{HCOOH}, 98 \%$ ), which were used for chromatographic analysis, were supplied by Sigma-Aldrich. The HA used in this study was Suwannee River Humic Acid, (SRHA, 2S101H), which was obtained from the International Humic Substances Society (IHSS, US) (Table S1). Sodium thiosulfate $\left(\mathrm{Na}_{2} \mathrm{~S}_{2} \mathrm{O}_{8}\right.$, chemically pure) was purchased from 
Sinopharm Chemical Reagent Co., Ltd. (Shanghai, China). All of these chemicals were used without any pre-treatment.

Ultrapure water used for sample preparation was obtained from the Milli-Q water purification system (Millipore Synergy 185, US). The pharmaceutical sample solutions were stored in the dark at $4{ }^{\circ} \mathrm{C}$. All the experiments were performed at $\mathrm{pH} 6.0 \pm 0.1$.

\subsection{Ozonation Experiments Setup}

The ozonation experimental system for the study was consisted of an oxygen cylinder, an $\mathrm{O}_{3}$ gas generator (Model 3S-X, KIRIS, China), and a reaction reactor device. The $\mathrm{O}_{3}$ gas was generated by passing pure $\mathrm{O}_{2}$ feed gas $(99.9 \%)$ through the $\mathrm{O}_{3}$ generator equipped with a gaseous flow meter. Then continuously sparged $\mathrm{O}_{3}$ gas into the bottom of the reactor using a fine bubble diffuser at a constant flow rate of $1 \mathrm{~L} / \mathrm{min}$. Excess $\mathrm{O}_{3}$ was passed into two gas absorption bottles containing $2 \%$ KI solution.

\subsection{TMP Ozonation Study}

\subsubsection{Removal of TMP in $\mathrm{O}_{3}$ Solution}

Four experimental conditions were prepared, including TMP $(10 \mathrm{mg} / \mathrm{L})$ in ultrapure water, in methanol solution $(0.25 \mathrm{~mol} / \mathrm{L})$, in HA solution $(15 \mathrm{mg} / \mathrm{L})$, and in mixed solution of HA $(15 \mathrm{mg} / \mathrm{L})$ and methanol $(0.25 \mathrm{~mol} / \mathrm{L})$. The solutions were designed to study the effect of the additional NOM and free radical quencher (methanol for $\cdot \mathrm{OH}$ ) on the ozonation of TMP.

First, $\mathrm{O}_{3}$ gas was introduced into ultrapure water at $0{ }^{\circ} \mathrm{C}$ (in ice bath). The concentration of $\mathrm{O}_{3}$ in the water increased gradually, and the corresponding concentration of $\mathrm{O}_{3}$ solution was obtained by controlling the aeration time. Afterward, $50 \mathrm{~mL}$ of the water matrix (the concentration was twice that of the above four conditions) was added into a conical flask, and $50 \mathrm{~mL}$ of $\mathrm{O}_{3}$ solution from the reactor was added to the conical flask. In this way, the concentration of the corresponding substance in the mixed solution meet the set experimental conditions. The solution was mixed before determining its concentration to ensure that the reaction was complete (in $1 \mathrm{~min}$ ), and sodium thiosulfate solution was added to the sample to stop the reaction. At the same time, $5 \mathrm{~mL}$ of $\mathrm{O}_{3}$ solution was obtained to determine the concentration of $\mathrm{O}_{3}$. The initial concentration of dissolved $\mathrm{O}_{3}$ was calculated by dividing the concentration in $\mathrm{O}_{3}$ solution by 2. To ensure accuracy, all experiments were conducted in triplicate.

The effects of $\mathrm{HA}$ and $\mathrm{OH}$ on TMP degradation were studied by comparing the degradation of TMP in four experimental conditions.

\subsubsection{Ozonation of TMP in $\mathrm{O}_{3}$ Contactor}

The experimental condition in this study was similar to that in Section 2.3.1 except that the reactor was stirred continuously using a magnetic stirrer at $20^{\circ} \mathrm{C}$, and $\mathrm{O}_{3}$ gas was directly introduced into four water substrates to react with the pollutants. Samples were obtained at corresponding times, and sodium thiosulfate solution was added to the sample to stop the reaction. To ensure that the amount of the products was above the detection limit of the HPLC-MS/MS, the initial TMP concentration was set at $10 \mathrm{mg} / \mathrm{L}$. The experiments were carried out in a continuously aerated reactor containing TMP solution with an initial $\mathrm{pH}$ of $6.0 \pm 0.1$, and the amounts of the residual parent compounds and the formation of intermediate products were detected by HPLC-MS/MS at regular time intervals. Samples for EEM detection were also taken before the beginning of the experiment and at the 5th, 10th, and 30th min of the experiment.

\subsection{Analytical Methods}

The concentration of $\mathrm{O}_{3}$ was determined according to the "Standard Methods for the Examination of Water and Wastewater (21st Ed)-APHA (2005)-Method 4500-O ${ }_{3}$-Indigo Colorimetric Method". More detailed information and procedures about indigo method can be found in the literature [55]. 
TMP concentration and the abundance of intermediate products during the TMP degradation process was determined according to the HPLC-MS/MS system (Agilent 1290-6460, USA) with an Agilent C18 column $(3.5 \mu \mathrm{m}, 2.1 \times 150 \mathrm{~mm})$. The column temperature was maintained at $40{ }^{\circ} \mathrm{C}$. Mobile phase A was ultrapure water containing $0.1 \%$ formic acid, and mobile phase B was methanol (99\%). The following gradient program was used for the analysis: $90 \%$ A (initial), $90-80 \%$ A (1.0-1.5 min), 80-60\% A (1.5-3.5 min), 60\% A (3.5-6.0 min), 60-40\% A (6.0-6.5 min), 40\% A (6.5-7.0 min), $40-0 \%$ A $(7.0-7.5 \mathrm{~min}), 0 \% \mathrm{~A}(7.5-10.5 \mathrm{~min})$, and 0-90\% A (10.5-11.0 $\mathrm{min})$. The injection volume was $10 \mu \mathrm{L}$. The column temperature was maintained at $40{ }^{\circ} \mathrm{C}$. The flow rate of the mobile phase was $0.3 \mathrm{~mL} / \mathrm{min}$. For the elucidation of the intermediates, positive ionization mode was used to acquire the intermediates with a scan range of $\mathrm{m} / \mathrm{z} 50$ to $\mathrm{m} / \mathrm{z} 600$.

Fluorescence spectrometer (FS5, Edinburgh Instruments, Livingston, UK) was used to measure the changes of the fluorescent substances in the reaction process. The parameters were set as follows: scanning speed of $12,000 \mathrm{~nm} / \mathrm{min}$, data interval of $5.0 \mathrm{~nm}$, excitation light bandwidth of $3.0 \mathrm{~nm}$, and emission light bandwidth of $3.0 \mathrm{~nm}$. The excitation wavelength $\left(E_{\mathrm{x}}\right)$ was set to $230-450 \mathrm{~nm}$ and the emission wavelength $\left(E_{m}\right)$ was $260-550 \mathrm{~nm}$.

The toxicity of TMP and its degradation products were predicted using the Toxicity Estimation Software Tool (V4.2.1, USEPA, 2016).

\section{Results and Discussion}

\subsection{Removal Efficiency of TMP by Ozonation}

\subsubsection{Removal Efficiency of TMP in $\mathrm{O}_{3}$ Saturated Water}

The mass transfer rate of $\mathrm{O}_{3}$ increases with the increase of $\mathrm{O}_{3}$ concentration [56]. Therefore, the concentration of $\mathrm{O}_{3}$ played an important effect on the degradation of TMP. Liu et al. [57] carried out ozonation experiments on eight kinds of antibiotics, including ampicillin, azithromycin, erythromycin, clarithromycin, ofloxacin, sulfamethoxazole, trimethoprim, and tetracycline, and the results showed that ozonation rate was highly depended on $\mathrm{O}_{3}$ concentration and contact time, and the removal efficiency of antibiotics increased with the increase of $\mathrm{O}_{3}$ concentration. As shown in Figure 1a, with the increase of $\mathrm{O}_{3}$ concentration, the removal efficiency of TMP increased. $\mathrm{O}_{3}$ dosage was positively correlated with TMP removal efficiency.



(a)

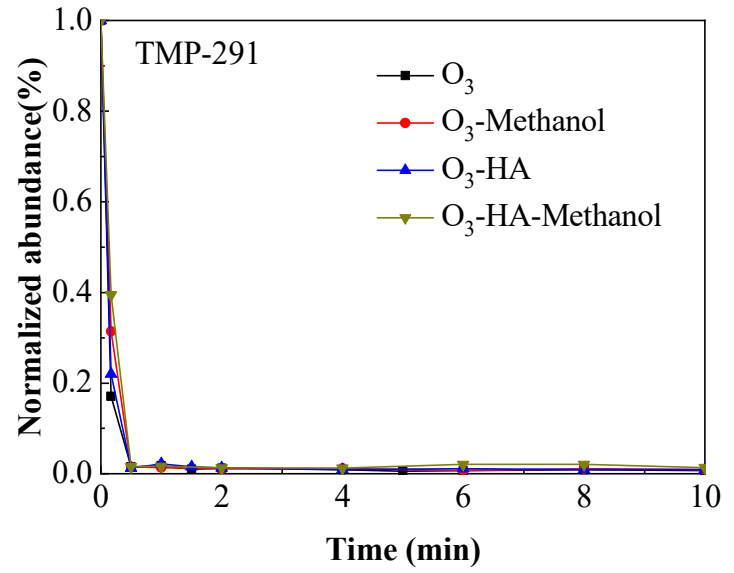

(b)

Figure 1. Effect of $\mathrm{O}_{3}$ concentration on Trimethoprim (TMP) removal efficiency (a) (initial TMP concentration $=10 \mathrm{mg} / \mathrm{L}$, initial $\mathrm{pH}=6.0 \pm 0.1,0^{\circ} \mathrm{C}$ ) and the ozonation rate of TMP in four water substrates $(\mathbf{b})$ (initial TMP concentration $=10 \mathrm{mg} / \mathrm{L}$, initial $\mathrm{pH}=6.0 \pm 0.1,20^{\circ} \mathrm{C}$ ). 
After adding HA, the removal efficiency of TMP was lower than that of the TMP solution without adding any substance. Moreover, HA may cause competitive degradation, thereby inhibiting the degradation of TMP [58]. When the concentration of $\mathrm{O}_{3}$ was not excessive, methanol can inhibit the removal efficiency of TMP solution in the presence and absence of HA. It can be seen in Figure 1a, when the $\mathrm{O}_{3}$ concentration was approximately $15 \mathrm{mg} / \mathrm{L}$, the removal efficiency of TMP in the $\mathrm{O}_{3}$ solution was $32 \%$. After adding HA, the removal efficiency reduced to $25 \%$. Under the condition of low concentration of $\mathrm{O}_{3}$, the inhibition of methanol on TMP degradation was evident. The removal efficiency of TMP was only $8 \%$ in the solution with HA and $15 \%$ without HA. Given that methanol has quenching effect on $\cdot \mathrm{OH}$, when $\mathrm{O}_{3}$ was not excessive, the indirect oxidation of $\mathrm{O}_{3}$ occupied the dominant position in reaction.

\subsubsection{Removal Efficiency of TMP in $\mathrm{O}_{3}$ Contactor}

As shown in Figure $1 b, \mathrm{O}_{3}$ can rapidly degrade TMP into other small molecular compounds within $1 \mathrm{~min}$. The addition of HA and methanol had little effect on the experimental results, indicating that TMP can be directly oxidized by $\mathrm{O}_{3}$ molecules.

\subsection{Degradation Pathway of TMP}

The intermediate products of TMP and the abundance of each product during ozonation were determined by using HPLC-MS/MS. The intermediate products produced during TMP degradation and their potential pathways are shown in Figure 2. The main transformation pathway of TMP in the degradation process was hydroxylation, demethylation, carbonylation, and cleavage $[59,60]$. In these reactions, hydroxylation was the main way of TMP degradation, since $\cdot \mathrm{OH}$ can be connected to any ring or methylene bridge of a TMP molecule [34]. The direct hydroxylation products of TMP can be expressed by the formula $\mathrm{C}_{14} \mathrm{H}_{19} \mathrm{~N}_{4} \mathrm{O}_{3+\mathrm{x}}$ [34], including T12 $(\mathrm{m} / \mathrm{z}=307)$ to T16 $(\mathrm{m} / \mathrm{z}=371)$ [61]. Carbonylation was also one of the main reaction pathways, which mainly occurred on a methylene bridge and a pyrimidine ring. The reactive bridging methylene group of TMP was attacked to form a carbonylation product $\mathrm{T} 1$ ( $\alpha$-ketotrimethoprim $\mathrm{m} / \mathrm{z}=305)$. The carbonylation of $\mathrm{T} 2(\mathrm{~m} / \mathrm{z}=325)$ occurred to a pyrimidine ring, and then it was attacked by $\cdot \mathrm{OH}$ to produce hydroxylation products including T3 $(\mathrm{m} / \mathrm{z}=341)$ to T5 $(\mathrm{m} / \mathrm{z}=373)$. Products T6 $(\mathrm{m} / \mathrm{z}=127), \mathrm{T} 7(\mathrm{~m} / \mathrm{z}=141)$, and T8 $(\mathrm{m} / \mathrm{z}=143)$ confirmed the methylene bridge cracking of TMP. The demethylation products of $\mathrm{T} 9(\mathrm{~m} / \mathrm{z}=277)$, $\mathrm{T} 10(\mathrm{~m} / \mathrm{z}=263)$, and $\mathrm{T} 11(\mathrm{~m} / \mathrm{z}=249)$ followed the formula of $\mathrm{C}_{14-\mathrm{y}} \mathrm{H}_{19-2 \mathrm{y}} \mathrm{N}_{4} \mathrm{O}_{3+\mathrm{x}}$ (y varying from 1 to 3) [62]. Demethylation was always accompanied by hydroxylation products. T17 (m/z $=293)$ to $\mathrm{T} 30(\mathrm{~m} / \mathrm{z}=313)$, which were produced under the joint action of demethylation and hydroxylation, were the hydroxylation products of the above three substances. The toxicity of TMP and its degradation products was evaluated using "Toxicity Estimation Software Tool" (V4.2.1, USEPA, 2016) (Table S2), indicating that no products with significant toxicity were formed during the reaction. 


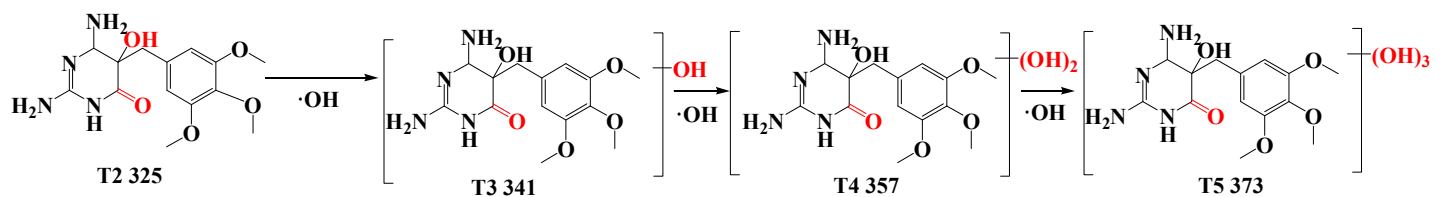
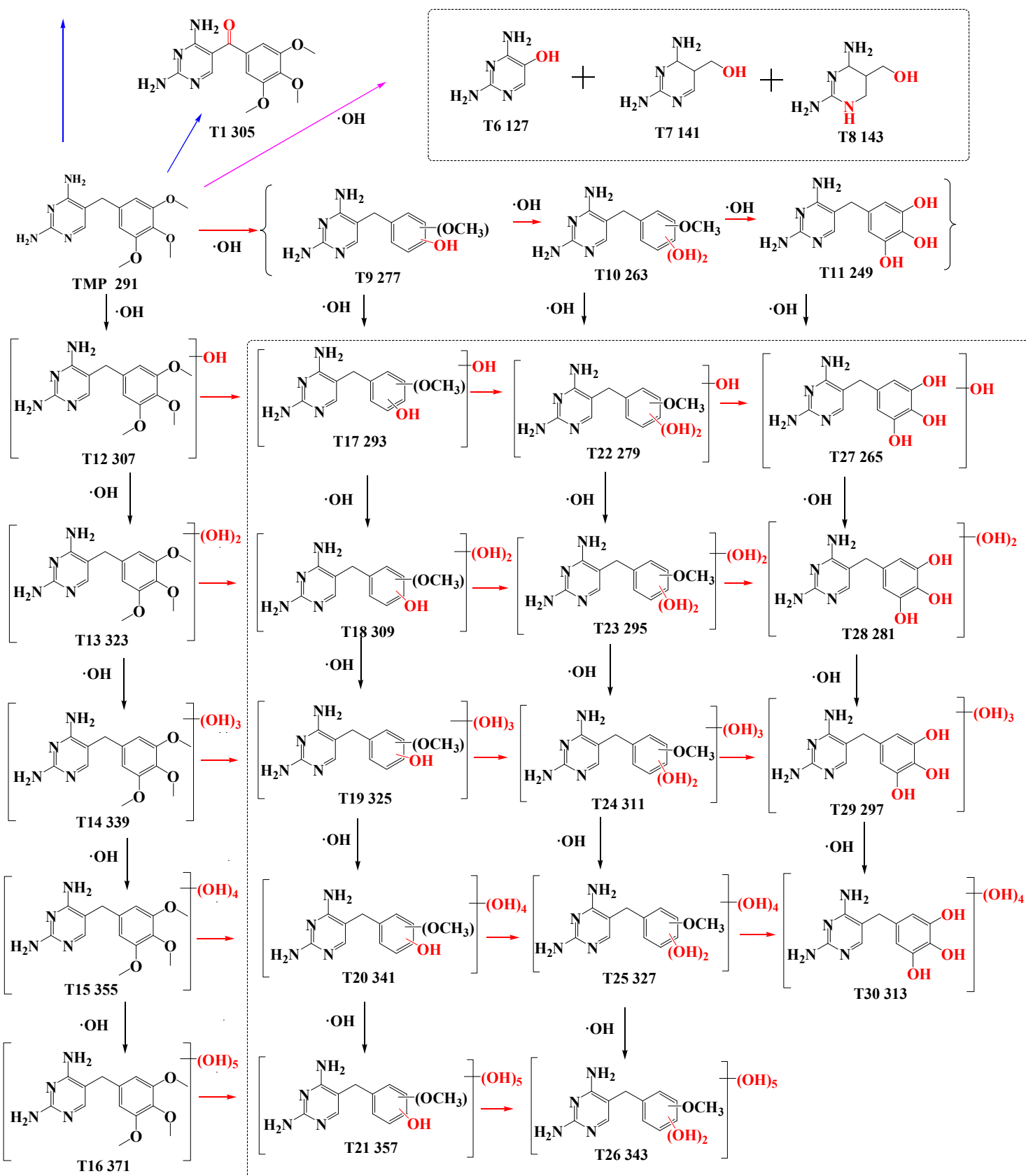

Он

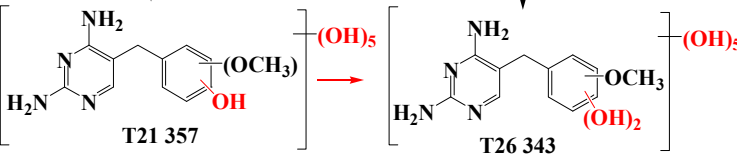

Demethylation \& Hydroxylation

Hydroxylation

Carbonylation

Cleavage

Demethylation

Figure 2. The intermediate products and potential pathways of TMP during ozonation.

TMP was degraded rapidly within 5 min after the start of the reaction, and intermediate products were formed at the same time. The variation of the abundance of the intermediate products during the experiment is shown in Figures 3-6. T1 and T2 were both carbonylation products of TMP, which accumulated rapidly at the beginning of the reaction, and then rapidly degraded. T1 remained 
stable in the later stage, whereas T2 might continue to react with the oxidant to produce T3, T4, and T5. The reaction trend of $\mathrm{T} 2$ was the same with that of T3, which was completely degraded to form T5 within 2 min. The amount of T5 in solution was low and degraded slowly until the region was stabilized. Owing to the quenching effect of methanol on $\cdot \mathrm{OH}$, methanol can inhibit the production of most intermediates. As shown in Figure 3, after adding methanol, the removal efficiency of TMP decreased slightly, but the change was not significant, which indicated that direct oxidation was the dominant role in carbonylation. The maximum abundance of cleavage reaction products was only $0.01 \%$, which degraded rapidly after accumulation to the peak. Figure $4 \mathrm{a}-\mathrm{c}$ showed that the addition of methanol reduced the amount of T7 by half, and almost no other cleavage products were produced, which indicating that indirect oxidation was the dominant role in cleavage reaction. As shown in Figure $4 \mathrm{~d}-\mathrm{f}$, the peak accumulation of demethylation product T9 to T11 occurred at approximately 2 min after the reaction, and then decreased slowly. As demethylation products, T9 and T11 were also affected by methanol. The addition of methanol not only affected the demethylation of TMP, but also inhibited the subsequent replacement of the second methoxyl group by the hydroxyl group. The quenching of $\cdot \mathrm{OH}$ by methanol restricted hydroxylation reaction and significantly reduced the hydroxylation products T12 to T16 in Figure 5. T12 was the direct hydroxylation product of TMP, which accumulated rapidly in the early stage of the reaction, and then degraded rapidly to form the subsequent polyhydroxylation products (T16 and other intermediate products), which remained stable after 2 min. The amount of T16 had little change during the reaction process. When methanol was added to the solution, the direct hydroxylation product of T12 was significantly reduced, which indicated that indirect oxidation was dominant in the reaction process. The common products of hydroxylation and demethylation are shown in Figure 6. The generation of T17 to T30 was close to that of hydroxylation product T15, but significantly higher than those of demethylation products including T9 to T11. The reason may be that TMP was attacked by $\cdot \mathrm{OH}$ at the same time of demethylation, or the hydroxylated product of TMP undergoes a demethylation reaction, which resulting in a relatively high abundance of T21. However, due to the complexity of the reaction, determining the dominant reaction was difficult.
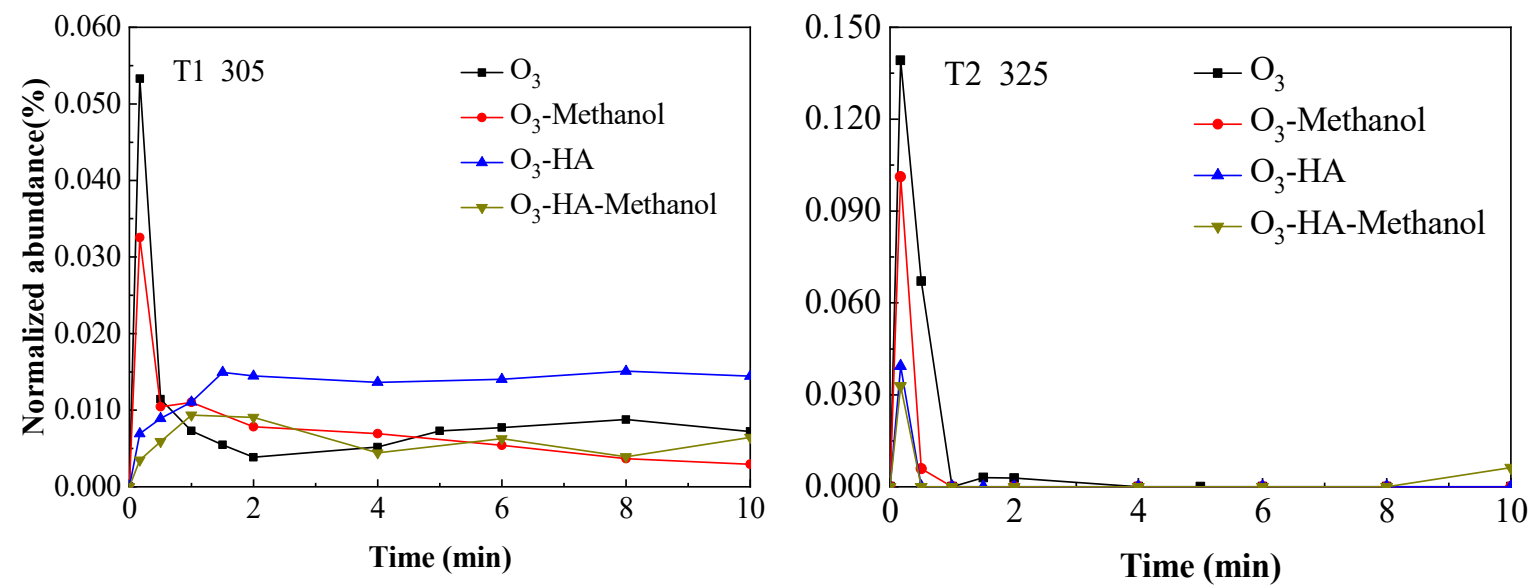

Figure 3. Formation of carbonylation products during TMP ozonation (initial TMP concentration $=10 \mathrm{mg} / \mathrm{L}$, initial $\left.\mathrm{pH}=6.0 \pm 0.1,20^{\circ} \mathrm{C}\right)$. 



Figure 4. Formation of cleavage $(\mathbf{a}-\mathbf{c})$ and demethylation $(\mathbf{d}-\mathbf{f})$ products during TMP ozonation (initial $\mathrm{TMP}$ concentration $=10 \mathrm{mg} / \mathrm{L}$, initial $\mathrm{pH}=6.0 \pm 0.1,20^{\circ} \mathrm{C}$ ).

The addition of HA had a great influence on the degradation of TMP and the formation of intermediate products, which completely inhibited the formation of the carbonylation products T1 and T2. As for the cleavage products, HA inhibited the production of the products in both of the solutions in the presence and absence of methanol. The inhibition effect of HA on indirect oxidation in the reaction was clear, but when HA and methanol existed together, the product abundance in the solution was almost zero except for T7. HA had little effect on demethylation products T9 and T10, but it inhibited the subsequent demethylation product T11. When methanol was added to the solution, only T9 can be produced. This result meant that indirect oxidation reaction played an important role in the demethylation reaction. HA significantly inhibited the hydroxylation products except T12 to T16. 

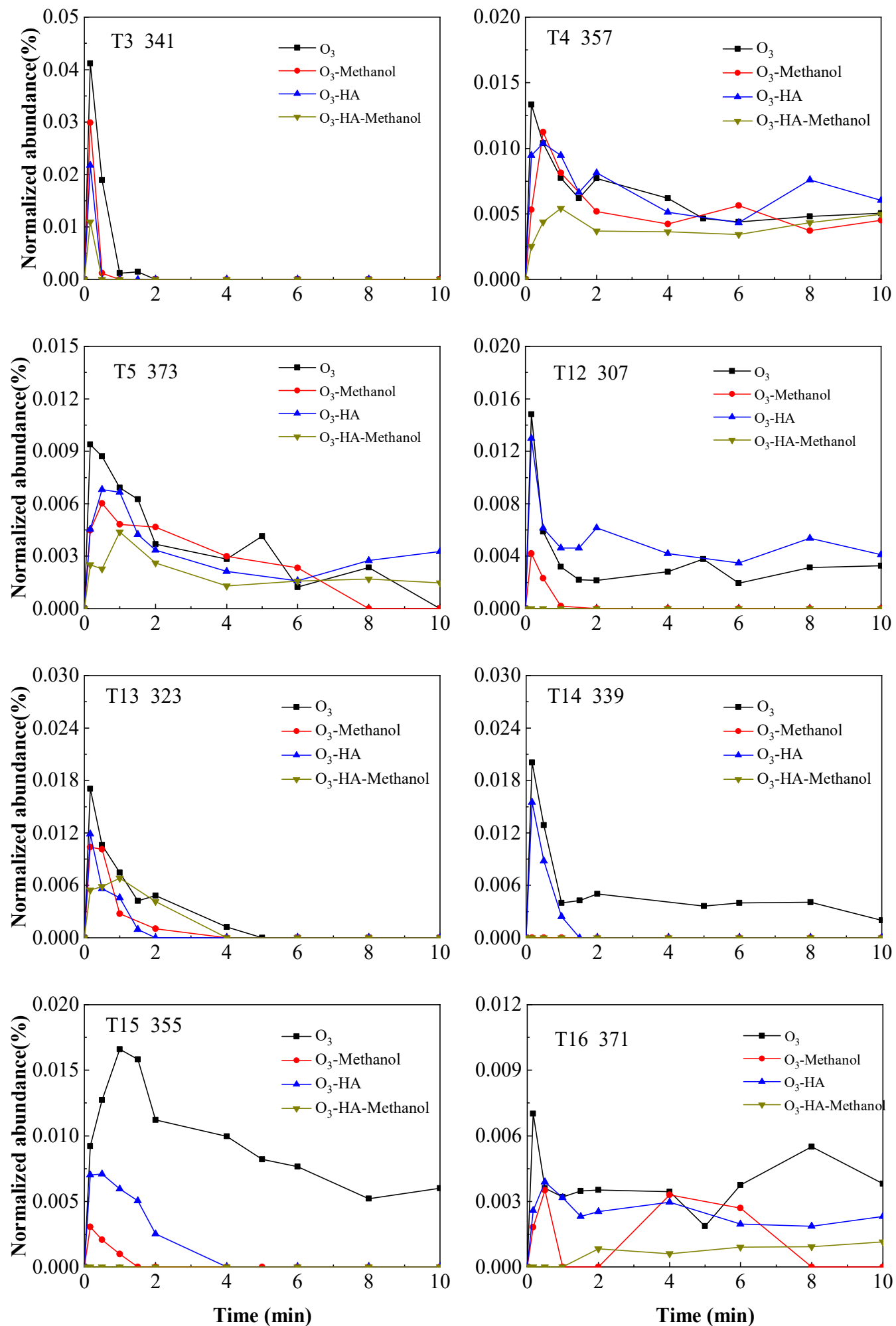

Figure 5. Formation of hydroxylation products during TMP ozonation (initial TMP concentration $=10 \mathrm{mg} / \mathrm{L}$, initial $\mathrm{pH}=6.0 \pm 0.1,20^{\circ} \mathrm{C}$ ). 

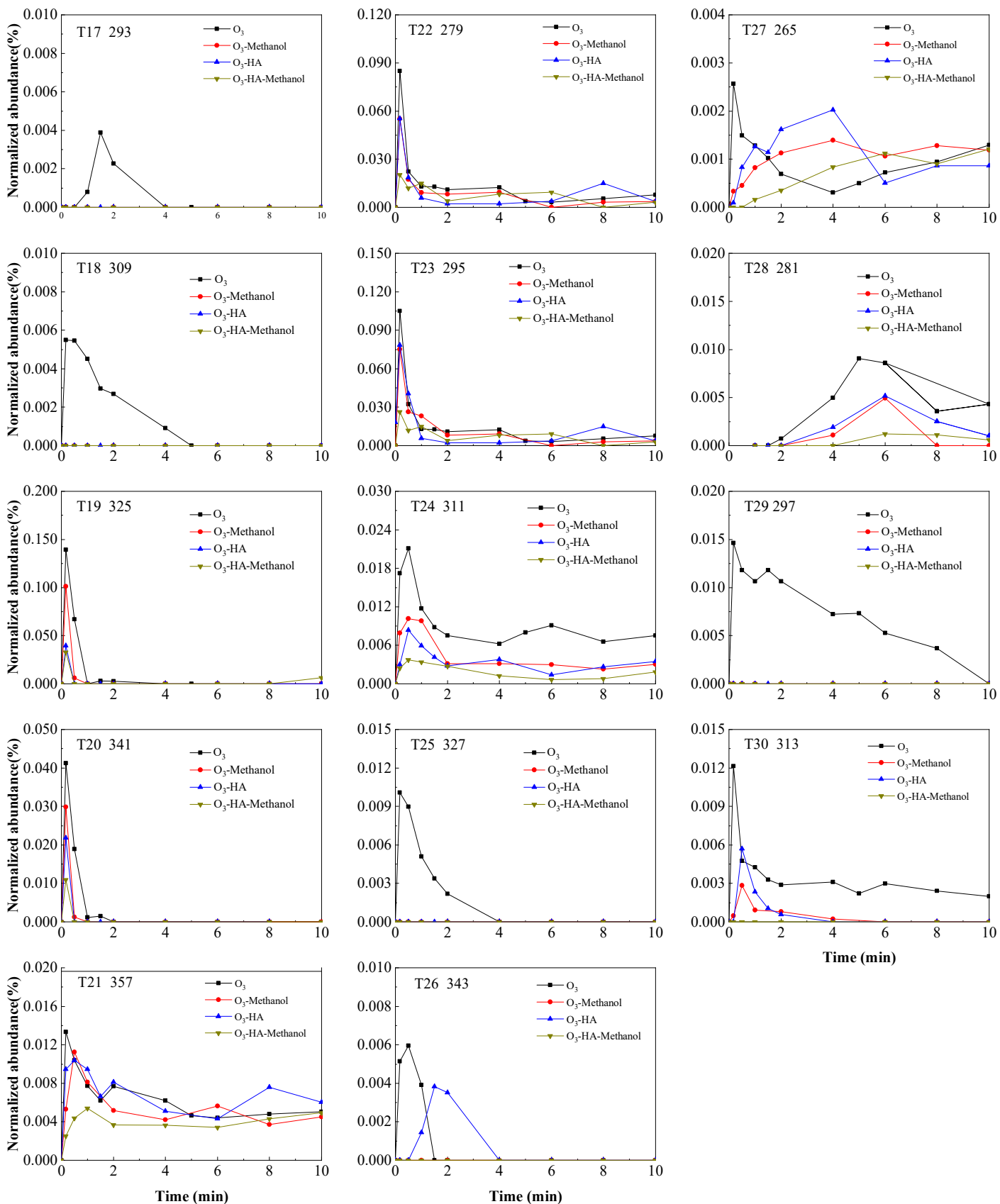

Figure 6. Formation of hydroxylated demethylation products during TMP ozonation (initial TMP concentration $=10 \mathrm{mg} / \mathrm{L}$, initial $\left.\mathrm{pH}=6.0 \pm 0.1,20^{\circ} \mathrm{C}\right)$.

\subsection{EEM Analysis}

$\mathrm{O}_{3}$ could oxidize not only the TMP, but also the HA in water. HA have good fluorescence characteristics, which can be quantitatively and qualitatively analyzed by using fluorescence spectroscopy. The changes of fluorescence substances during the experiment are shown in Figure 7. Fluorescence peak (b) was at $E_{x} / E_{m}=270 \mathrm{~nm} / 490 \mathrm{~nm}$, and the peak value was close to 9000 . Peak (a) at $E_{x} / E_{m}=425 \mathrm{~nm} / 475 \mathrm{~nm}$ was not evident. After the $\mathrm{O}_{3}$ was introduced into the solution, Peak (a) and Peak (b) were shifted towards shorter wavelengths (blue-shifted) from $480 \mathrm{~nm}$ to $450 \mathrm{~nm}$ along the excitation axis. The fluorescence value of peak (a) was higher than that of peak (b). Moreover, the fluorescence value gradually decreased with the progress of the reaction. The emission wavelength of peak (a) was short, which indicated that the substance represented by peak (a) has simple structure 
and low aromatization level. The decrease of peak (a) value after the introduction of $\mathrm{O}_{3}$ indicated that the substances with simple structure were preferentially degraded. The fluorescence intensity of peaks (a) and (b) decreased rapidly to $74.84 \%$ and $43.28 \%$ after 5 min of ozonation, and gradually decreased to $28.18 \%$ and $13.66 \%$ after $30 \mathrm{~min}$ of ozonation. The changes of fluorescence substances of solution with TMP and HA are also shown in Figure 7. Compared with those in the absence of TMP, the peak patterns of the fluorescence substances changed significantly after TMP was introduced. The peak value increased obvious, and peak (a) was shifted towards shorter wavelengths (blue-shifted), which indicated that more aromatics were formed.

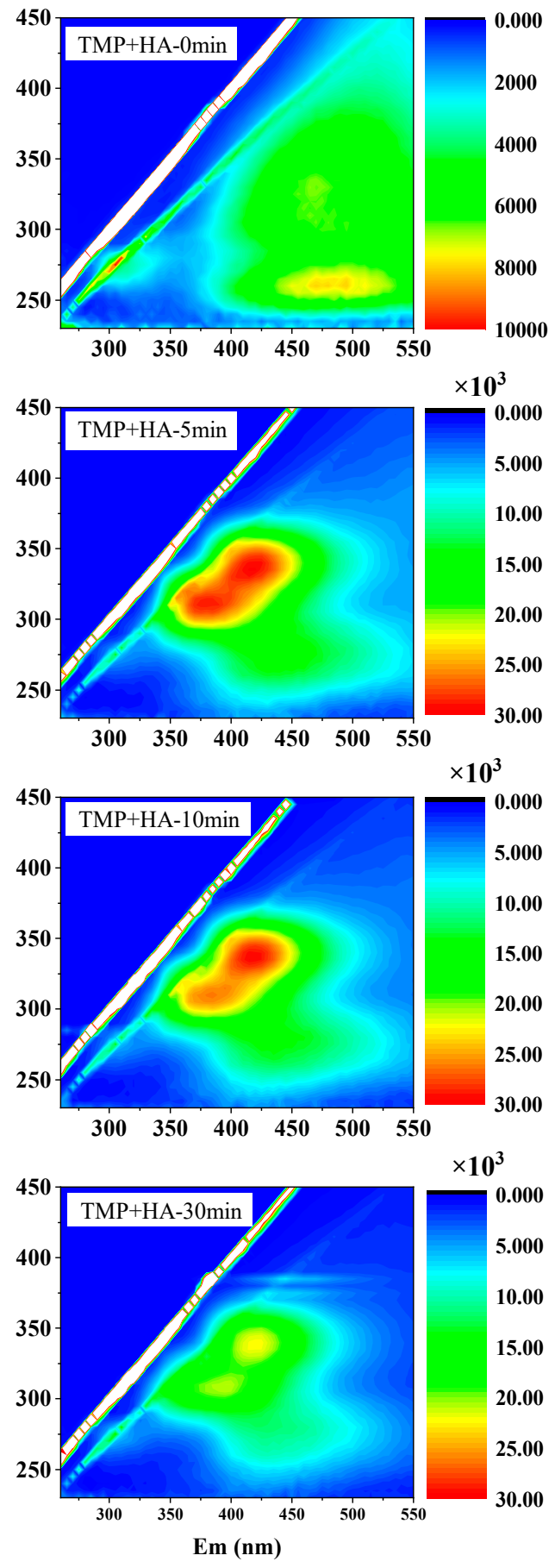

Figure 7. 3D-EEM analysis of ozonation of humic acids (HA) solution and TMP solution added with HA. 
The structure of $\mathrm{HA}$ was changed by the reaction of $\mathrm{O}_{3}$ in the solution. The decrease of fluorescence value in solution indicates that $\mathrm{O}_{3}$ can degrade $\mathrm{HA}$ and its products. The change of peak position in Figure 7 shows that HA not only formed competitive degradation with TMP, but also affected the ozonation of TMP.

\section{Conclusions}

Excessive $\mathrm{O}_{3}$ can degrade TMP rapidly, and the addition of HA and methanol had little effect on the reaction, indicating that TMP could be directly oxidized by $\mathrm{O}_{3}$ molecules. When $\mathrm{O}_{3}$ was not excessive, the removal efficiency of TMP increased with the increase of $\mathrm{O}_{3}$ dosage. The addition of HA and methanol inhibited the degradation of TMP. Therefore, indirect oxidation also played an important role in the removal of TMP.

The reaction pathways proposed were hydroxylation, demethylation, cleavage, and carbonylation. In particular, hydroxylation was the dominant reaction. The existence of HA in water may affect the generation of cleavage and carbonylation products of TMP significantly, and the formation of hydroxylated products and demethylation products also decreased slightly. According to the free radical quenching test, the cleavage and demethylation products were mainly produced by indirect oxidation. With the extension of ozonation time, the fluorescence value in the solution decreased and the fluorescence peak blue shifted, indicating that the structure of HA changed in the reaction and was competitively degraded with TMP.

Ozone oxidation technology not only has a fast degradation rate, but also can remove odor without producing secondary pollution. Although ozone oxidation only leads to partial oxidation of drugs, due to the high removal rate and the small quantities of products, partial oxidation is enough to reduce pharmacological activity and toxicity. Ozonation has a high potential for the oxidation of pharmaceuticals in drinking water and wastewater. This study could provide theoretical basis for the control of TMP and its ozonation products during water treatment.

Supplementary Materials: The following are available online at http://www.mdpi.com/2073-4441/12/10/2935/s1. Table S1: The characteristics of SRHA (data from IHSS), Table S2: Toxicological values of TMP and its products during ozonation.

Author Contributions: N.Z. and R.Y. make equal contributions to conception and design, and/or acquisition of data, and/or analysis, interpretation of data and writing the manuscript; B.Z., F.W., and H.C. participate in revising the manuscript critically for important intellectual content; and give final approval of the version to be submitted and any revised version. All authors have read and agreed to the published version of the manuscript.

Funding: This work was financially supported by the Beijing Natural Science Foundation (8182034), the National Environmental and Energy Base for International Science \& Technology Cooperation (41822706), and the Fundamental Research Funds for the Central Universities (FRF-TP-19-001C1).

Acknowledgments: The experimental supporting by National Environmental and Energy Base for International Science \& Technology Cooperation was greatly appreciated.

Conflicts of Interest: The authors declare that they have no known competing financial interests or personal relationships that could have appeared to influence the work reported in this paper.

\section{References}

1. Kumar, A.; Rana, A.; Sharma, G.; Naushad, M.; Dhiman, P.; Kumari, A.; Stadler, F.J. Recent advances in nano-Fenton catalytic degradation of emerging pharmaceutical contaminants. J. Mol. Liq. 2019, 290, 111177. [CrossRef]

2. Padhye, L.P.; Yao, H.; Kung'u, F.T.; Huang, C.H. Year-long evaluation on the occurrence and fate of pharmaceuticals, personal care products, and endocrine disrupting chemicals in an urban drinking water treatment plant. Water Res. 2014, 51, 266-276. [CrossRef] [PubMed]

3. Richardson, S.D.; Ternes, T.A. Water Analysis: Emerging Contaminants and Current Issues. Anal. Chem. 2005, 77, 3807-3838. [CrossRef] [PubMed]

4. González, B.; Trujillano, R.; Vicente, M.A.; Rives, V.; Korili, S.A.; Gil, A. Photocatalytic degradation of trimethoprim on doped Ti-pillared montmorillonite. Appl. Clay Sci. 2019, 167, 43-49. [CrossRef] 
5. Kumar, M.; Jaiswal, S.; Sodhi, K.K.; Shree, P.; Singh, D.K.; Agrawal, P.K.; Shukla, P. Antibiotics bioremediation: Perspectives on its ecotoxicity and resistance. Environ. Int. 2019, 124, 448-461. [CrossRef]

6. Duan, Y.; Deng, L.; Shi, Z.; Liu, X.; Zeng, H.; Zhang, H.; Crittenden, J. Efficient sulfadiazine degradation via in-situ epitaxial grow of Graphitic Carbon Nitride $\left(\mathrm{g}-\mathrm{C}_{3} \mathrm{~N}_{4}\right)$ on carbon dots heterostructures under visible light irradiation: Synthesis, mechanisms and toxicity evaluation. J. Colloid Interface Sci. 2020, 561, 696-707. [CrossRef] [PubMed]

7. Santos, L.H.; Araujo, A.N.; Fachini, A.; Pena, A.; Delerue-Matos, C.; Montenegro, M.C. Ecotoxicological aspects related to the presence of pharmaceuticals in the aquatic environment. J. Hazard Mater. 2010, 175, 45-95. [CrossRef] [PubMed]

8. Yuan, R.; Zhu, Y.; Zhou, B.; Hu, J. Photocatalytic oxidation of sulfamethoxazole in the presence of $\mathrm{TiO}_{2}$ : Effect of matrix in aqueous solution on decomposition mechanisms. Chem. Eng. J. 2019, 359, 1527-1536. [CrossRef]

9. Challis, J.K.; Carlson, J.C.; Friesen, K.J.; Hanson, M.L.; Wong, C.S. Aquatic photochemistry of the sulfonamide antibiotic sulfapyridine. J. Photochem. Photobiol. A Chem. 2013, 262, 14-21. [CrossRef]

10. Rong, S.-P.; Sun, Y.-B.; Zhao, Z.-H. Degradation of sulfadiazine antibiotics by water falling film dielectric barrier discharge. Chin. Chem. Lett. 2014, 25, 187-192. [CrossRef]

11. Garoma, T.; Umamaheshwar, S.K.; Mumper, A. Removal of sulfadiazine, sulfamethizole, sulfamethoxazole, and sulfathiazole from aqueous solution by ozonation. Chemosphere 2010, 79, 814-820. [CrossRef] [PubMed]

12. Li, N.; Zhang, Y.H.; Xiong, X.L.; Li, Z.G.; Jin, X.H.; Wu, Y.N. Study of the physicochemical properties of trimethoprim with beta-cyclodextrin in solution. J. Pharm. Biomed. 2005, 38, 370-374. [CrossRef]

13. Anjali, R.; Shanthakumar, S. Insights on the current status of occurrence and removal of antibiotics in wastewater by advanced oxidation processes. J. Environ. Manag. 2019, 246, 51-62. [CrossRef] [PubMed]

14. de Paula, F.C.; de Pietro, A.C.; Cass, Q.B. Simultaneous quantification of sulfamethoxazole and trimethoprim in whole egg samples by column-switching high-performance liquid chromatography using restricted access media column for on-line sample clean-up. J. Chromatogr. A 2008, 1189, 221-226. [CrossRef]

15. Li, R.; Huang, J.; Cai, M.; Huang, J.; Xie, Z.; Zhang, Q.; Liu, Y.; Liu, H.; Lv, W.; Liu, G. Activation of peroxymonosulfate by $\mathrm{Fe}$ doped $\mathrm{g}-\mathrm{C}_{3} \mathrm{~N}_{4}$ /graphene under visible light irradiation for Trimethoprim degradation. J. Hazard Mater. 2020, 384, 121435. [CrossRef] [PubMed]

16. Wang, J.; Zhuan, R.; Chu, L. The occurrence, distribution and degradation of antibiotics by ionizing radiation: An overview. Sci. Total Environ. 2019, 646, 1385-1397. [CrossRef]

17. Ji, Y.; Xie, W.; Fan, Y.; Shi, Y.; Kong, D.; Lu, J. Degradation of trimethoprim by thermo-activated persulfate oxidation: Reaction kinetics and transformation mechanisms. Chem. Eng. J. 2016, 286, 16-24. [CrossRef]

18. Focazio, M.J.; Kolpin, D.W.; Barnes, K.K.; Furlong, E.T.; Meyer, M.T.; Zaugg, S.D.; Barber, L.B.; Thurman, M.E. A national reconnaissance for pharmaceuticals and other organic wastewater contaminants in the United States-II) untreated drinking water sources. Sci. Total Environ. 2008, 402, 201-216. [CrossRef]

19. Thiebault, T. Sulfamethoxazole/Trimethoprim ratio as a new marker in raw wastewaters: A critical review. Sci. Total Environ. 2020, 715, 136916. [CrossRef]

20. Majumder, A.; Gupta, B.; Gupta, A.K. Pharmaceutically active compounds in aqueous environment: A status, toxicity and insights of remediation. Environ. Res. 2019, 176, 108542. [CrossRef]

21. Moreira, F.C.; Boaventura, R.A.R.; Brillas, E.; Vilar, V.J.P. Degradation of trimethoprim antibiotic by UVA photoelectro-Fenton process mediated by Fe (III)-carboxylate complexes. Appl. Catal. B Environ. 2015, 162, 34-44. [CrossRef]

22. Martínez-Costa, J.I.; Rivera-Utrilla, J.; Leyva-Ramos, R.; Sánchez-Polo, M.; Velo-Gala, I. Individual and simultaneous degradation of antibiotics sulfamethoxazole and trimethoprim by UV and solar radiation in aqueous solution using bentonite and vermiculite as photocatalysts. Appl. Clay Sci. 2017. [CrossRef]

23. Liu, Q.; Li, M.; Liu, X.; Zhang, Q.; Liu, R.; Wang, Z.; Shi, X.; Quan, J.; Shen, X.; Zhang, F. Removal of sulfamethoxazole and trimethoprim from reclaimed water and the biodegradation mechanism. Front. Environ. Sci. Eng. 2018, 12, 6. [CrossRef]

24. Sui, Q.; Huang, J.; Deng, S.; Yu, G.; Fan, Q. Occurrence and removal of pharmaceuticals, caffeine and DEET in wastewater treatment plants of Beijing, China. Water Res. 2010, 44, 417-426. [CrossRef] [PubMed]

25. Angela, L.; Batt, S.K.; Aga, D.S. Comparison of the occurrence of antibiotics in four full-scale wastewater treatment plants with varying designs and operations. Chemosphere 2007, 68, 428-435. [CrossRef] 
26. Göbel, A.; Thomsen, A.; McArdell, C.S.; Joss, A.; Giger, W.; Joss, A. Occurrence and Sorption Behavior of Sulfonamides, Macrolides, and Trimethoprim in Activated Sludge Treatment. Environ. Sci. Technol. 2005, 39, 3981-3989. [CrossRef]

27. Richard, H.; Lindberg, U.; Olofsson, P.; Rendahl, M.; Johansson, I.; Tysklind, M.; Andersson, B.A.V. Behavior of Fluoroquinolones and Trimethoprim during Mechanical, Chemical, and Active Sludge Treatment of Sewage Water and Digestion of Sludge. Environ. Sci. Technol. 2006, 40, 1042-1048.

28. Sui, Q.; Huang, J.; Deng, S.; Chen, W.; Yu, G. Seasonal variation in the occurrence and removal of pharmaceuticals and personal care products in different biological wastewater treatment processes. Environ. Sci. Technol. 2011, 45, 3341-3348. [CrossRef]

29. Cecconet, D.; Molognoni, D.; Callegari, A.; Capodaglio, A.G. Biological combination processes for efficient removal of pharmaceutically active compounds from wastewater: A review and future perspectives. J. Environ. Chem. Eng. 2017, 5, 3590-3603. [CrossRef]

30. Sharma, P.R.; Sharma, S.K.; Lindström, T.; Hsiao, B.S. Nanocellulose-Enabled Membranes for Water Purification: Perspectives. Adv. Sustain. Syst. 2020, 4. [CrossRef]

31. Sharma, P.R.; Sharma, S.K.; Borges, W.; Chen, H.; Hsiao, B.S. Remediation of $\mathrm{UO}_{2}{ }^{2+}$ from Water by Nitro-Oxidized Carboxycellulose Nanofibers: Performance and Mechanism. In Contaminants in Our Water: Identification and Remediation Methods; American Chemical Society: Washington, DC, USA, 2020; Volume 1352, pp. 269-283.

32. Chen, H.; Sharma, S.K.; Sharma, P.R.; Yeh, H.; Johnson, K.; Hsiao, B.S. Arsenic(III) Removal by Nanostructured Dialdehyde Cellulose-Cysteine Microscale and Nanoscale Fibers. ACS Omega 2019, 4, 22008-22020. [CrossRef]

33. Luo, X.; Zheng, Z.; Greaves, J.; Cooper, W.J.; Song, W. Trimethoprim: Kinetic and mechanistic considerations in photochemical environmental fate and AOP treatment. Water Res. 2012, 46, 1327-1336. [CrossRef] [PubMed]

34. Michael, I.; Hapeshi, E.; Osorio, V.; Perez, S.; Petrovic, M.; Zapata, A.; Malato, S.; Barceló, D.; Fatta-Kassinos, D. Solar photocatalytic treatment of trimethoprim in four environmental matrices at a pilot scale: Transformation products and ecotoxicity evaluation. Sci. Total Environ. 2012, 430, 167-173. [CrossRef]

35. Zhan, C.; Li, Y.; Sharma, P.R.; He, H.; Sharma, S.K.; Wang, R.; Hsiao, B.S. A study of $\mathrm{TiO}_{2}$ nanocrystal growth and environmental remediation capability of $\mathrm{TiO}_{2} / \mathrm{CNC}$ nanocomposites. RSC Adv. 2019, 9, 40565-40576. [CrossRef] [PubMed]

36. Oneby, M.A.; Bromley, C.O.; Borchardt, J.H.; Harrison, D.S. Ozone Treatment of Secondary Effluent at U.S. Municipal Wastewater Treatment Plants. Ozone Sci. Eng. 2010, 32, 43-55. [CrossRef]

37. Huber, M.M.; Canonica, S.; Park, G.-Y.; von Gunten, U. Oxidation of Pharmaceuticals during Ozonation and Advanced Oxidation Processes. Environ. Sci. Technol. 2003, 37, 1016-1024. [CrossRef] [PubMed]

38. Khan, A.H.; Khan, N.A.; Ahmed, S.; Dhingra, A.; Singh, C.P.; Khan, S.U.; Mohammadi, A.A.; Changani, F.; Yousefi, M.; Alam, S.; et al. Application of advanced oxidation processes followed by different treatment technologies for hospital wastewater treatment. J. Clean. Prod. 2020, 269, 122411. [CrossRef]

39. Wang, H.; Mustafa, M.; Yu, G.; Ostman, M.; Cheng, Y.; Wang, Y.; Tysklind, M. Oxidation of emerging biocides and antibiotics in wastewater by ozonation and the electro-peroxone process. Chemosphere 2019, 235, 575-585. [CrossRef] [PubMed]

40. Wang, J.; Zhuan, R. Degradation of antibiotics by advanced oxidation processes: An overview. Sci. Total Environ. 2020, 701, 135023. [CrossRef]

41. Staehelln, J.; Holgné, J. Decomposition of Ozone in Water Rate of Initiation by Hydroxide Ions and Hydrogen Peroxide. Environ. Sci. Technol. 1982, 16, 676-681. [CrossRef]

42. Yargeau, V.; Leclair, C. Impact of Operating Conditions on Decomposition of Antibiotics during Ozonation: A Review. Ozone Sci. Eng. 2008, 30, 175-188. [CrossRef]

43. Von Gunten, U. Ozonation of drinking water: Part, I. Oxidation kinetics and product formation. Water Res. 2003, 37, 1443-1467. [CrossRef]

44. Elovitz, M.S.; von Gunten, U.; Kaiser, H.-P. Hydroxyl Radical/Ozone Ratios during Ozonation Processes. II. The Effect of Temperature, pH, Alkalinity, and DOM Properties. Ozone Sci. Eng. 2000, 22, 123-150. [CrossRef]

45. Haag, W.R.; Yao, C.C.D. Rate Constants for Reaction of Hydroxyl Radicals with Several Drinking Water Contaminants. Environ. Sci. Technol. 1992, 26, 1005-1013. [CrossRef] 
46. Michael, C.D.; Buffle, M.; Gunten, U.V. Oxidation of Antibacterial Molecules by Aqueous Ozone: Moiety-Specific Reaction Kinetics and Application to Ozone-Based Wastewater Treatment. Environ. Sci. Technol. 2006, 40, 1969-1977.

47. Ling, W.; Ben, W.; Xu, K.; Zhang, Y.; Yang, M.; Qiang, Z. Ozonation of norfloxacin and levofloxacin in water: Specific reaction rate constants and defluorination reaction. Chemosphere 2018, 195, 252-259. [CrossRef] [PubMed]

48. Kuang, J.; Huang, J.; Wang, B.; Cao, Q.; Deng, S.; Yu, G. Ozonation of trimethoprim in aqueous solution: Identification of reaction products and their toxicity. Water Res. 2013, 47, 2863-2872. [CrossRef]

49. Kima, H.; Yooa, H.; Honga, S.; Leea, S.; Parkc, B.; Parkd, H.; Leee, C.; Leef, J. Effects of inorganic oxidants on kinetics and mechanisms of $\mathrm{WO}_{3}$-mediated photocatalytic degradation. Appl. Catal. B Environ. 2015, 163, 515-523. [CrossRef]

50. Ternes, T.A.; Stüber, J.; Herrmann, N.; McDowell, D.; Ried, A.; Kampmann, M.; Teiser, B. Ozonation: A tool for removal of pharmaceuticals, contrast media and musk fragrances from wastewater? Water Res. 2003, 37, 1976-1982. [CrossRef]

51. Audenaert, W.T.M.; Vandierendonck, D.; Van Hulle, S.W.H.; Nopens, I. Comparison of ozone and HO induced conversion of effluent organic matter (EfOM) using ozonation and $\mathrm{UVH}_{2} \mathrm{O}_{2}$ treatment. Water Res. 2013, 47, 2387-2398. [CrossRef]

52. Quaranta, M.L.; Mendes, M.D.; MacKay, A.A. Similarities in effluent organic matter characteristics from Connecticut wastewater treatment plants. Water Res. 2012, 46, 284-294. [CrossRef] [PubMed]

53. Lee, C.Y.; Lee, Y. Impact of Water Quality on the Formation of Bromate and Formaldehyde during Water Ozonation. J. Environ. Health Sci. 2007, 33, 441-450. [CrossRef]

54. Conde-Cida, M.; Fernández-Calviñoa, D.; Nóvoa-Muñoza, J.C.; Arias-Estéveza, M.; Díaz-Raviñab, M.; Núñez-Delgadoc, A.; Fernández-Sanjurjoc, M.J.; Álvarez-Rodríguezc, E. Degradation of sulfadiazine, sulfachloropyridazine and sulfamethazine in aqueous media. J. Environ. Manag. 2018, 228, 239-248. [CrossRef] [PubMed]

55. Bader, H.; Hoigné, J. Determination of ozone in water by the indigo method. Water Res. 1981, 15, 449-569. [CrossRef]

56. Zhao, W.; Wu, Z.; Wang, D. Ozone direct oxidation kinetics of Cationic Red X-GRL in aqueous solution. J. Hazard Mater. 2006, 137, 1859-1865. [CrossRef] [PubMed]

57. Liu, Y.; Guo, H.; Zhang, Y.; Cheng, X.; Zhou, P.; Deng, J.; Wang, J.; Li, W. Highly efficient removal of trimethoprim based on peroxymonosulfate activation by carbonized resin with Co doping: Performance, mechanism and degradation pathway. Chem. Eng. J. 2019, 356, 717-726. [CrossRef]

58. Iakovides, I.C.; Michael-Kordatou, I.; Moreira, N.F.F.; Ribeiro, A.R.; Fernandes, T.; Pereira, M.F.R.; Nunes, O.C.; Manaia, C.M.; Silva, A.M.T.; Fatta-Kassinos, D. Continuous ozonation of urban wastewater: Removal of antibiotics, antibiotic-resistant Escherichia coli and antibiotic resistance genes and phytotoxicity. Water Res. 2019, 159, 333-347. [CrossRef]

59. Zhang, Z.; Yang, Q.; Wang, J. Degradation of trimethoprim by gamma irradiation in the presence of persulfate. Radiat. Phys. Chem. 2016, 127, 85-91. [CrossRef]

60. Samy, M.; Ibrahim, M.G.; Gar Alalm, M.; Fujii, M.; Ookawara, S.; Ohno, T. Photocatalytic degradation of trimethoprim using $\mathrm{S}-\mathrm{TiO}_{2}$ and $\mathrm{Ru} / \mathrm{WO}_{3} / \mathrm{ZrO}_{2}$ immobilized on reusable fixed plates. J. Water Process Eng. 2020, 33, 101023. [CrossRef]

61. Tay, K.S.; Rahman, N.A.; Abas, M.R.B. Characterization of atenolol transformation products in ozonation by using rapid resolution high-performance liquid chromatography/quadrupole-time-of-flight mass spectrometry. Microchem. J. 2011, 99, 312-326. [CrossRef]

62. Sirtori, C.; Aguera, A.; Gernjak, W.; Malato, S. Effect of water-matrix composition on Trimethoprim solar photodegradation kinetics and pathways. Water Res. 2010, 44, 2735-2744. [CrossRef] [PubMed]

Publisher's Note: MDPI stays neutral with regard to jurisdictional claims in published maps and institutional affiliations. 